\title{
MEANS AND METHODS OF COMBAT - DIFFERING PARAMETERS AND REQUIREMENTS OF MILITARY NECESSITY IN INTERNATIONAL HUMANITARIAN LAW AND INTERNATIONAL CRIMINAL LAW
}

\author{
James Gallagher \\ LLM PAPER \\ LAWS 533: LAW OF ARMED CONFLICT
}

FACULTY OF LAW

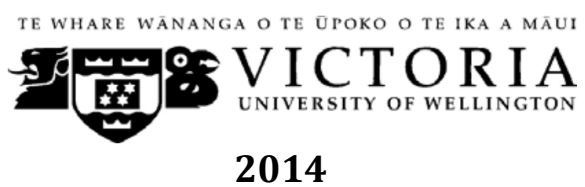




\section{CONTENTS}

I. INTRODUCTION - MILITARY NECESSITY .................................................

II. NECESSITY IN INTERNATIONAL HUMANITARIAN LAW ...........................

A. Origins of Military Necessity - Treaty Law and Customary International

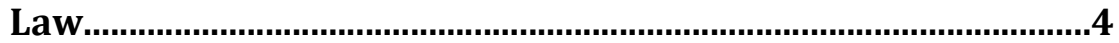

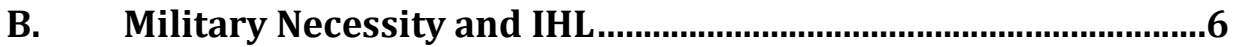

III. MILITARY NECESSITY - INTERNATIONAL ORGANISATIONS'

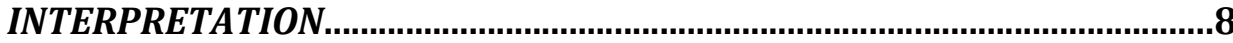

C. The International Committee of the Red Cross..........................8

D. The United Nations...............................................................................9

IV. MILITARY NECESSITY AND ACTION

E. American Intervention..................................................................

F. NATO and the Kosovo Crisis.......................................................12

G. Military Necessity: NATO's Intervention.....................................14

H. The territorial application of military necessity......................17

V. MILITARY NECESSITY AND INTERNATIONAL CRIMINAL LAW ..............20

I. The Nuremberg Trials.........................................................................

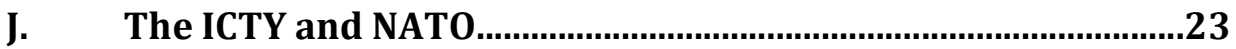

K. NATO and Breaches of IHL............................................................24

L. The ICJ on Military Necessity........................................................25

M. Military Necessity under Non International Armed

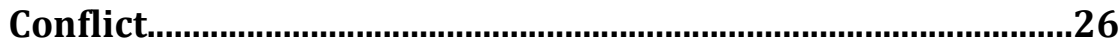

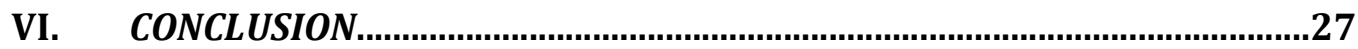

VII. BIBLIOGRAPHY

I. INTRODUCTION - MILITARY NECESSITY 
The concept of military necessity is of fundamental importance for International Humanitarian Law (IHL), International Criminal Law (ICL) and International Law, generally. States and individuals have used military necessity as a justification when extraordinary situations "require the adoption of measures departing from the normally applicable law in order to protect basic values and fundamental interests." 1 Measures adopted on the grounds of necessity have been accepted at international law by international courts and tribunals, state practice, and international legal doctrine.

This paper will analyse and explain the origins of military necessity under IHL, and how military necessity's use has developed and influenced the behaviour of actors at international law, primarily during times of armed conflict. Furthermore, this paper will seek to establish the role that military necessity plays at ICL. This will be done by analysing various case law examples of international tribunals where the tribunals have been asked to determine whether military necessity constituted a legitimate justification for a particular course of action taken by an individual, primarily in positions of command. This paper will highlight the circumstances where a legitimate finding of military necessity existed, and will contrast this to occasion where actions did not meet the required threshold. It will also seek to determine how military necessity is interpreted and understood by various international organisations such as the International Criminal Court (ICC), the United Nations (UN), and the International Committee of the Red Cross (ICRC).

The paper will begin with by providing an overview of the origins of military necessity under IHL and how it has evolved in its interpretation and usage by authors writing on military necessity, and states seeking to utilise it.

\section{NECESSITY IN INTERNATIONAL HUMANITARIAN LAW}

\footnotetext{
1 Tarcisio Gazzini, Wouter G. Werner and Ige F. Dekker "Necessity Across International Law: An Introduction" (2010) NYIL 41 at 3.
} 
Necessity generally is a central principle of international law. It is a "source of international rules[,] a condition for the application of certain ... rules as well as a circumstance precluding the wrongfulness of certain acts." ${ }^{2}$ Necessity, and specifically military necessity exist as a justification for actions that would otherwise be considered unlawful.

Under IHL, the starting point is based upon the premise that there is an armed conflict. IHL seeks to regulate armed conflict and " $[\mathrm{w}]$ hatever restraints the law imposes must accommodate [those restraints] to military necessity and regulate around its edges."3 This emphasises the point that terrible actions occur during times of war, and the laws of war "can only ... shrink [those terrible actions] to what is necessary[.]"4

\section{A. Origins of Military Necessity - Treaty Law and Customary International Law}

Military necessity as a principle of armed conflict dates back to the mid $19^{\text {th }}$ century following Henry Dunant's publication of Un Souvenir de Solferino, which inspired the establishment of the ICRC. However, the first official codification of the modern laws of war was promulgated by the United States during the American Civil War.

The Lieber $\operatorname{Code}^{5}$ provides an early example of the importance of military necessity and how it influences the actions of forces during an armed conflict. The code explicitly states that " $[\mathrm{m}]$ ilitary necessity ... consists in the necessity of those measures which are indispensible for securing the ends of the war, and which are lawful according to the modern law and usages of war." 6 Crucially, the Lieber Code accepts the need for actions that are intended to achieve the necessary goals and objectives of war, but seeks to ensure war is conducted with

\footnotetext{
${ }^{2}$ Nicholas Tsagourias "Necessity and the Use of Force: A Special Regime" (2010) NYIL 41 at 12.

${ }^{3}$ David Luban "Military Necessity and the Cultures of Military Law" (2013) Leiden Journal of International Law 26 at 323.

${ }^{4}$ Ibid.

${ }^{5}$ Instructions for the Government of Armies of the United States in the Field (Lieber Code) 24

April 1863.

${ }^{6}$ Art 14, Lieber Code.
} 
adherence to the legal conduct of war, and to act out of military necessity to achieve legitimate objectives.

Two sets of treaties, the Hague Treaty and the Geneva Convention, establish the core principles of IHL, including military necessity. These treaties impose a range of requirements and obligations upon parties that have ratified them. The Hague Treaties "sought to limit the tactics of war and prohibit the use of certain weapons that cause excessive suffering"7 Specifically, Hague Convention IV refers to the necessity of warfare with the "desire to diminish the evils of war, as far as military requirements permit[.]" 8 Additionally, the International Committee of the Red Cross in Geneva established a number of protections for people who are impacted by war, especially for those who do not directly participate in a conflict. These make up the treaties known as the Geneva Conventions.

The Geneva Convention Additional Protocols (AP) I and II help to further expand upon the requirements of military necessity under IHL. AP I ${ }^{9}$ eludes to the principle of military necessity under two main Articles. On the protection of the civilian population, AP I prohibits indiscriminate attacks by armed forces against civilians. ${ }^{10}$ The requirements to determine whether there is military necessity for an attack can also be determined under AP I, which states that indiscriminate attacks are prohibited if it is considered that such an attack "may be expected to cause incidental loss of civilian life, injury to civilians, damage to civilian objects, or a combination thereof, which would be excessive in relation to the concrete and direct military advantage anticipated."11 AP I also imposes requirements upon States to take precautions in the conduct of military operations. If before an attack takes place "it becomes apparent that the objective is not a military one ... or that the attack may be expected to cause

\footnotetext{
${ }^{7}$ Beth Van Schaack \& Kelly Madigan "Volume 2: International Criminal Law" (2014) International Humanitarian Law Teaching Supplement, Emroy International Humanitarian Law Clinic at 2.

${ }^{8}$ Hague Convention (IV) respecting the Laws and Customs of War on Land, 18 October 1907.

${ }^{9}$ Protocol Additional to the Geneva Conventions of 12 August 1949, and relating to the Protection of Victims of International Armed Conflicts (Protocol I), of June 1977.

10 Ibid, Art 51(4).

${ }^{11}$ Above, n 8, Art 51(5)(b).
} 
incidental loss of civilian life ... which would be excessive in relation to the concrete and direct military advantage anticipated[.]"12 Although articles 51 and 57 do not refer explicitly to the principle of military necessity, it is clear that a key parameter of military necessity exists in relation to the protection of civilians during an armed conflict. If it is considered that an attack may cause loss of civilian life that would be disproportionate to the military objective, it is arguable that this imposes a clear restriction on military necessity as a justification for action.

AP II provides additional restrictions on the application of military necessity and helps to define its parameters of applicability. Article 15 seeks to protect works and installations containing dangerous forces, such as dams, dykes and nuclear power stations by ensuring that such installations are not the object of attack "if such attack may cause the release of dangerous forces and consequent severe losses among the civilian population."13 It is clear that under AP II, the High Contracting Parties of AP II agreed that installations such as dams and nuclear power stations were to be the object of a military attack, the risk to the civilian population would outweigh any military benefit and places a further requirement on the use of military necessity as a justifying principle for military action.

\section{B. Military Necessity and IHL}

To assist with the understanding of what constitutes military necessity, a number of authors have written and provided interpretation of the various requirements of military necessity.

Writing after the World War II war crime trials, N.C.H. Dunbar argued there were three distinct categories of military necessity. The first category, he argued, proscribed "indirectly, what might otherwise constitute lawful acts of warfare by laying down the principle that 'no more force, no greater violence, should be used to carry out an operation than is absolutely necessary in the

${ }^{12}$ Above, $\mathrm{n} 8$ Art 57(2)(b).

${ }_{13}$ Protocol Additional to the Geneva Conventions of 12 August 1949, and relating to the Protection of Victims of Non-International Armed Conflicts (Protocol II), of 8 June 1977, Art 15. 
particular circumstances'."14 The second category of military necessity is made up of "rules by which State parties have specifically limited the circumstances in which military necessity is applicable." 15 This category relates to the Hague Treaties and Geneva Conventions and the specific prohibition on certain military activities unless determined to be absolutely militarily necessary. The third and final category, according to Dunbar, will be discussed later in this paper but highlights the "use of military necessity as an affirmative defense to war crimes."16

However, when considering military necessity in the context of the early $21^{\text {st }}$ century B J Bill suggests that it is inappropriate to describe military necessity as a specific rule of armed conflict, but rather a basic, and general rule of IHL. He argues military necessity "permeates all subsidiary rules [of the laws of war]."17 Instead, the focus on the application of military necessity should be to what extent it is has become part of particular rules of warfare. These other rules of warfare, according to Bill, demonstrate that military necessity is not prescribed a specific standard by the law of war and merely "offers a weak independent constraint at best."18 Furthermore, when analysing the rules related to the means and methods of warfare "almost all the rules are stated as prohibitions, many of which contain military necessity exceptions[.]"19 It is possible to suggest that based on Bill's reasoning, military necessity constitutes a vital part of IHL, but one that must be carefully considered in conjunction with specific rules, such as the treatment of prisoners of war and non-combatants.

Following post World War II pleadings by individuals charged for war crimes of military necessity as a general justification for violating IHL, "there has been a wide consensus that military necessity cannot justify conduct which disregards a

\footnotetext{
${ }^{14}$ N.C.H. Dunbar "Military Necessity in War Crimes Trials" [1952] 29 BYIL (1952).

15 B J Bill “The Rendlic 'Rule': Military Necessity, Commander's Knowledge, and Methods of Warfare” (2009) YIHL 12 at 129.

16 Ibid.

17 Above, n 15 at 131.

${ }^{18}$ Above, n 15 at 132 .

${ }^{19}$ Above, n 15 at 133.
} 
positive rule of law or which goes beyond its express limitations." 20 This arguably imposes a requirement that military necessity is interpreted as narrowly as possible.

\section{MILITARY NECESSITY - INTERNATIONAL ORGANISATIONS' INTERPRETATION}

As a result of the important role that military necessity plays in the actions of combatants during an armed conflict, a number of international organisations have in various ways provided insight into the status of military necessity today.

\section{The International Committee of the Red Cross}

The ICRC's publication, Handbook on International Rules Governing Military Operations ${ }^{21}$ collects summaries of what the ICRC considers to be the most important provisions of the law of armed conflict. It defines the law of armed conflict, or IHL, as a set of rules "which seek, for humanitarian reasons to limit the effects of armed conflict."22 This statement clearly emphasises and reflects the ICRC's mission and purpose of ensuring humanitarian protection and assistance for victims of armed conflict. The ICRC's interpretation of the rules of armed conflict show that they are intended to "strike a balance between considerations of military necessity and the requirements of humanity." 23 Furthermore, the ICRC's view of military necessity, unsurprisingly, reflects closely the language of treaties on the subject. Military necessity as defined by the ICRC, and taken from Treaty law is as follows:

The principle of military necessity permits measures which are actually necessary to accomplish a legitimate military purpose and are not otherwise prohibited by the law of armed conflict. In the case of an armed conflict the only legitimate military purpose is to weaken the military capacity of the other parties to the conflict. ${ }^{24}$

20 William Gerald Downey Jr "The Law of War and Military Necessity" (1953) 47(2) AJIL 251 at 262.

${ }^{21}$ International Committee of the Red Cross "Handbook on International Rules Governing Military Operations" ICRC, December 2013.

22 Ibid at 47.

23 Ibid.

${ }^{24}$ Above, n 21 at 54. 
This is a very narrow interpretation of the role that military necessity plays in IHL, but it represents the very concise and principled approach adopted by the ICRC.

\section{The United Nations}

Military necessity's position in international law and IHL can also be understood by analysing the United Nations (UN) position. The United Nations Infantry Battalion Manual provides specific guidance to battalion commanders and their staff highlighting how the planning and conduct of operations during peacekeeping operations should be executed in line with a UN mandate. Interestingly, the Manual makes no reference of military necessity, but instead refers to 'operational necessities'.

Despite developments since the late $20^{\text {th }}$ century, the UN's report on State responsibility further shows how the UN views military necessity under international law. Mr Roberto Ago, Special Rapporteur, provides valuable insight into what constitutes a state of necessity in international law. Mr Ago suggests that necessity, as an excuse, "may conceivably be accepted in international law only on condition that it is absolutely of an exceptional nature."25 However, in the report, military necessity is referred to as its own form of necessity, arising out of state responsibility. According to Mr Ago, and the UN, military necessity:

"constitutes the ratio, the raison d'être, of certain fundamental rules of the law of war and neutrality, namely, those which, in derogation of principles of peacetime law, confer on a belligerent State the legal right to resort, as against the enemy and its nationals ... to acts which peacetime law would forbid."

Through the language chosen by the UN, it can be understood that military necessity, while accepted, as a legitimate exercise of a state's sovereign right, should also only be considered when other options before a state have failed.

${ }^{25} \mathrm{R}$ Ago, Addendum - Eighth report on State responsibility by Mr. Roberto Ago, Special Rapporteur - the internationally wrongful act of the State, source of international responsibility YILC (1980) II(1) At 19. 


\section{International Court of Justice}

In its Advisory Opinion on the Legality of the Threat of Use of Nuclear Weapons, 26 the International Court of Justice (ICJ) provided a useful determination on the principle of military necessity in international law. This determination supports the Geneva Conventions concept of restricting military action where the civilian population would be put at significant risk. The ICJ determined that "States must never make civilians the object of attack and must consequently never use weapons that are incapable of distinguishing between civilian and military targets." 27 The ICJ continued "it is prohibited to cause unnecessary suffering to non combatants." 28 A pronouncement such as this provides a clear indication of an international court's opinion on how judgments around military necessity are to be made. It gives us insight into how tribunals will interpret the treaty law of the Hague Treaties and the Geneva Conventions, when used as a defence by individuals seeking to justify action as a military necessity.

\section{MILITARY NECESSITY AND ACTION}

Significant discussion and focus is placed upon the theoretical and legal interpretation of military necessity with further contemplation about possible applications of military necessity. Military necessity operates as both a restrictive, and permissive condition of IHL. The following section will seek to illustrate what military necessity looks like when it is used as a justification for action in recent examples of armed conflict. It will examine situations that required the balancing exercise to determine whether military necessity existed in order to justify intervention through military means.

Primary focus will be placed upon the North Atlantic Treaty Organization's (NATO's) operations during in the former Yugoslavia, also known as the Kosovo crisis. The criterion of military necessity is used as the bench mark determining whether action is justifiable, and this will be considered against what actions

\footnotetext{
${ }^{26}$ International Court of Justice, Legality of the Threat or use of Nuclear Weapons, Advisory Opinion of 8 July 1996.

27 Ibid at 97.

28 Ibid.
} 
NATO undertook, and whether these actions arguably met the military necessity threshold. This section will ask to what extent does territorial application apply to military necessity, and how close to a theatre of operation can an attack that is justified as militarily necessary be conducted. Furthermore, it is important to consider the possibility that whatever action is taken by military commanders is balanced between overall military objectives, and how these objectives may influence a decision based on a determination of military necessity.

Military necessity will also be considered in light of certain methods of combat, and the particular application of unmanned aerial vehicles (UAV's) or 'drones' to conduct warfare, and the decision-making process that must be, or should be, involved when using UAV's to complete military objectives.

\section{E. American Intervention}

As mentioned, NATO's intervention in Yugoslavia during the Kosovo Crisis provides an effective example of military necessity in a recent context. However, before discussing military necessity's application during the Kosovo Crisis, it is important to briefly discuss the American position on intervention, as America played a vital role in terms of NATO's ability to effectively intervene during the Kosovo Crisis and provide support. Military intervention is important in the context of military necessity because military necessity is arguably one of the key factors when determining whether to conduct a military operation

President George W. Bush, following the 9/11 attacks conducted operations in attempt to reassert American power and demonstrate its willingness to use such power. Karl Eikenberry argues that there are four factors involved when influencing the decision of whether military intervention should occur. He argues that firstly "since the end of the Cold War, the US has found it difficult to define a coherent and consistent international security strategy." 29 This lack of a coherent strategy is based on a large number of competing interests demanding considerations that often involve serious financial consequences. This

\footnotetext{
${ }^{29}$ K Eikenberry "The American Calculus of Military Intervention”, Survival: Global Politics and Strategy, (2014) vol 56 no 3, at 264.
} 
influences the second consideration, that "Americans view the serious domestic fiscal and political problems [of the US] ... as related in part to its involvement in the wars in Afghanistan and Iraq." 30 The third factor is that there is "Scepticism regarding the use of force."31 Finally, American military intervention, and whether or not it occurs, depends upon "the constitutional argument within the US government over the war-making authority[.]"32 He argues that the primary lesson American learnt from involvement in wars in Afghanistan and Iraq is one of caution and skepticism, suggesting America in the future should follow the dictum, "look before you leap."33 With this argument in mind, it is now necessary to turn to analysing one of America's involvement through NATO during the Kosovo Crisis.

\section{F. NATO and the Kosovo Crisis}

In 1999 NATO launched a bombing campaign against the Federal Republic of Yugoslavia (FRY), for the purpose of ending the repression of Kosovo's dominant ethnic Albanian population. The campaign launched by NATO "pushed at the boundaries of international law in at least two important respects."34 The decision to engage in large-scale military action, without the consent of the UN Security Council authorisation "raised significant doubts about the status of the law governing the use of force and the viability of [UN] primacy in matters of international peace and security." 35 However, the second important aspect is more significant for the purposes of the role that military necessity played during NATO's campaign. This is centered around “NATO's high-altitude bombing campaign, conducted without a single NATO combat casualty but with significant civilian casualties within the FRY. ${ }^{36}$ The significant numbers of civilian casualties therefore requires an understanding of the purpose of NATO's intervention and how its intervention was conducted.

\footnotetext{
30 Ibid at 265.

31 Ibid.

32 Above, $\mathrm{n} 29$ at 266.

${ }^{33}$ Above, n 29 at 269.

${ }^{34}$ D Wippman "Kosovo and the Limits of International Law" (2001) 25 Fordham Int'l L.J 129 at 129.

35 Ibid.

36 Ibid.
} 
It must be remembered that military necessity primarily operates as a general principle of restraint. Humanitarian considerations must come as secondary to the fact that " $[\mathrm{m}]$ ilitary necessity, as understood by modern civilized nations, consists in the necessity of those measures which are indispensable for securing the ends of the war, and which are lawful according to the modern law and usages of war." 37 Therefore, military necessity can be seen as having "a restraining effect, since it imposes restrictive standard on the exercise of warfare: a belligerent must refrain from employing any kind or degree of violence which is not actually necessary for military purposes."38 Allowing derogation from international norms is a basic aspect of military necessity, codified under Article 35 of AP I. Article 35(1) states that during an armed conflict, "the right of the Parties to the conflict to choose methods or means of warfare is not unlimited." This is supported by Article 35(2) that prohibits the use of weapons including projectiles and material and methods of warfare "of a nature to cause superfluous injury or unnecessary suffering." The requirements of AP I and II are of vital importance and are helpful when seeking to determine whether NATO actions during the Kosovo crisis could be determined militarily necessary.

NATO airstrikes were undertaken as a way to end the ethnic cleansing taking place in Kosovo. Whether air strikes were the most effective means of intervention remains the subject of debate. As a result of how the genocide was taking place, showed that "[s]ome elements ... were clearly open to air attack, others, including many of the ground operation units, much less ... so."39 However, it was argued that the "basic reasoning behind the decision to adopt air strikes as a sole tactical method seems to have been founded upon a desire ... to minimize NATO causalities." 40 Additionally, air strikes provided an effective

\footnotetext{
${ }^{37}$ Art 14, Instructions for the Government of Armies of the United States in the Field (Lieber Code), 1863.

${ }^{38} \mathrm{G}$ Venturini "Necessity in the Law of Armed Conflict and in International Criminal Law" (2010) 41 NYIL 45 at 48.

${ }^{39}$ H McCoubrey "Kosovo, Nato and International Law" (1999) 14 International Relations 29 at 38.

40 Ibid.
} 
means of achieving military objectives without a protracted commitment of ground forces.

The choice by NATO to use air strikes to conduct its operations against Serbian forces is significant in terms of military necessity requirements. Additional Protocols I and II of 1977 highlight important factors to be considered when determining whether NATO's operations met the threshold of being militarily necessary. For example, Article 48 states:

In order to ensure respect for and protection of the civilian population and civilian objects, the Parties to the conflict shall at all times distinguish between the civilian population and combatants and between civilian objects and military objectives and accordingly shall direct their operations only against military objectives.

During the air strike campaign a number of targets were identified as civilian objects, and it was argued that NATO was in clear violation of Article 48.

\section{G. Military Necessity: NATO's intervention}

One of the key issues faced by NATO during its bombing campaign was trying to properly distinguish between military and civilian targets. Proximity to a military target is crucial for determining whether an attack could be justified as coming within the requirements of military necessity. A number of occasions during NATO's bombing campaign demonstrated that collateral damage during an operation occurred, but whether that damage fell outside the scope of military necessity is debatable.

According to Human Rights Watch, NATO's bombs killed between 500 and 1800 civilians, while wounding thousands more civilians. ${ }^{41}$ During NATO's attack, they "hit not only military forces and facilities, but also destroyed Yugoslavia's entire public infrastructure, inflicting an estimated $\$ 4$ billion of damage on bridges, highways, railroads, civilian airports, oil refineries, factories, construction equipment ... hospitals, schools ... houses ... and hundreds of acres

\footnotetext{
${ }^{41}$ Human Rights Watch World Report "New Figures on Civilian Deaths in Kosovo War" (7 February 2000) <www.hrw.org/hrw/press/2000/02/nato207/htm>.
} 
of forest." 42 Such collateral damage would appear that NATO violated very basic elements of IHL not to target or attack civilians. To what extent then, could these attacks be justified by military necessity? The strikes, which resulted in civilian deaths and injuries were carried out by aircraft which "dropped more than 38,000 sorties 15,000 feet about the ground to protect its airplanes and pilots."43 This method of conducting military operations, according to Amnesty International, "made full adherence to international humanitarian law virtually impossible." 44

The NATO air campaign's purpose was clear, primarily it was "to weaken Serb military capabilities, both strategically and tactically." 45 From the strategic point of view, strikes targeted clear military objectives including artillery and military field headquarters, which had an immediate effect in the disruption of Serbian ethnic cleansing. In conjunction with the strategic strikes, more tactical objectives included government ministries and refineries, which, while not immediately offering direct military advantages, caused disruption to the greater Serbian military organisation. In his article on the proportionality of NATO's campaign against Yugoslavia Fenrick states that the "choice of targets.... must be viewed within the content of contemporary theories for the use of aerospace power." 46 One such theory is the 'Five Strategic Rings' theory, put forward by Colon John A. Warden, USAF. This theory suggests that five rings "represent a different facet of a nation's society, [and the theory] lays the foundation for the notion of targeting national infrastructure to attack the enemy from the 'inside out'[.]" 47 This approach should be viewed with caution because of the inherent risk that objects that offer no definite military advantage are targeted or damaged during an attack. This theory arguably does not fit the requirements of IHL because even though "[p]roponents of the ... theory do not

\footnotetext{
42 M Cohen "NATO Bombing of Kosovo: Humanitarian Intervention or Crime Against Humanity?" [2002] 79 IJSL at 80.

43 Ibid.

${ }^{44}$ Amnesty International "NATO violations of the laws of war during Operation Allied Force must be investigated", (25 July 2000) <www.amnesty.org/news/2000/4/002500.htm>.

45 W.J. Fenrick "Targeting and Proportionality during NATO Bombing Campaign against Yugoslavia" [2001] 12 EJIL 489 at 490.

46 Ibid at 491.

47 Ibid.
} 
suggest that the enemy civilian population should be attacked ... they do believe that one of the objectives in war-fighting is to affect adversely civilian support for the enemy war effort." 48 This statement also stands in stark opposition to the general principles of IHL including Article 51 of AP I. Specifically, Article 51(2) states that "[t]he civilian population ... shall not be the object of attack. Acts or threats of violence the primary purpose of which is to spread terror among the civilian population are prohibited." Article 51 also provides for the prohibition of indiscriminate attacks where there is no direct military objective and where a military attack could harm military and civilian objects without distinction.

While Article 51 prohibits attacks on civilians prime facie, but Article 52 acknowledges that civilian objectives may become militarised if such objects can contribute to military action. In this way military necessity acts as "a limiting factor ... [by] implicitly recogni[sing] the lawful nature of weapons that cause militarily necessary suffering." 49 Following Schmitt, it could be argued that NATO action during its bombing campaign, despite resulting civilian casualties, was justified because of military necessity, because the need to destablise the Serbian military's ability to effectively conduct operations.

NATO's military objectives were outlined following the end of its campaign in Yugoslavia, these objectives demonstrate the extent to which military necessity was used to justify NATO intervention. NATO's key objectives during the campaign were to “[d]emonstrate the seriousness of NATO's opposition to Belgrade's aggression in the Balkans ... [d] eter Milosevic from continuing and escalating his attacks on helpless civilians and ... reverse his ethnic cleansing; and [d]amage Serbia's capacity to wage war against Kosovo."50 The International Criminal Tribunal for the Former Yugoslavia (ICTY) appears to support NATO action. The ICTY "emphasized that the prohibition on terrorizing a civilian

\footnotetext{
48 Ibid.

${ }^{49}$ M N Schmitt "Military Necessity and Humanity in International Humanitarian Law: Preserving the Delicate Balance" [2010] 50 VJIL 795 at 802.

${ }^{50}$ Cohen and Shelton "Joint Statement on Kosovo After Action Review in the US Mission to NATO" Security Issues Digest, (14 October 1999) at 6.
} 
population applies only when the operation was designed to cause terror."51 While in this context the ICTY was determining whether the actions of Serbian forces were specifically designed to cause terror to the civilian population, it is possible to assume that NATO's actions were, despite causing terror to the civilian population, were not designed to cause terror.

Aaron Schwabach, writing during NATO's operations, questioned the legality of NATO's bombing. While NATO's primary justification for intervention was to prevent genocide, Schwabach draws attention to the fact that the UN Charter "contains no provision allowing the use of force to prevent such atrocities."52 Although he does not refer to military necessity as a justification for military intervention, Schwabach is extremely critical of NATO action, going so far to state that it "does not appear that there is currently a customary international law norm permitting the use of force by states to prevent other states from killing or expelling their own populations." ${ }^{53}$ However, consequences for NATO's actions were arguably less severe than Serbia's.

\section{H. The territorial application of military necessity}

A proper assessment of military objectives is necessary before an operation is conducted. The war on terror, currently being fought against various terrorist groups, led by the United States, provides another example of military necessity in operation. A recent development in armed conflict is the use of UAVs to complete surgical strikes against specific targets. The use of UAVs has raised questions about the legality of such weapons. In terms of military necessity, as was demonstrated during the Kosovo Crisis, NATO was operating within a defined territory, and its targets were within that territory. However, the present conflict has shown that military targets are often spread throughout a large area, and are not fixed.

\footnotetext{
${ }^{51}$ Above, $\mathrm{n} 49$ at 816.

${ }^{52}$ A Schwabach "The Legality of the NATO Bombing Operation in the Federal Republic of Yugoslavia [1999] 11 Pace Int'l L Rev 405 at 416.

53 Ibid at 418.
} 
Ryan Vogel presents a number of issues that are raised when employing the use of UAVs. Regardless of whether an attack meets proportionality, necessity and humanity requirements of IHL, the following issues present themselves as recurring throughout the use of UAVs. Vogel asks if it matters whether "the host government consents to the strike, expressly opposes the strike, or is silent on the matter?"54 This raises the further question of whether the justification of military necessity has such wide-ranging applicability that an operation could be conducted well outside any defined theatre of operation. He continues by asking if a strike is still considered legal under IHL "if the strike takes place within the recognized battlefield of Afghanistan, the border region of Pakistan, the ungoverned spaces of Somalia; or the terrorist havens of Yemen?"55 These questions result from the nature of the armed conflict that the United States and its allies find itself in.

The Authorisation for the Use of Military Force (AUMF) "provides the authority for the use of military force [but] offers a great deal of ambiguity for its application." 56 This ambiguity is necessary for the current conflict because of the geographical expansiveness of the conflict zone, but critics of the United States operations argue "targeting operations conducted outside the geographical battlefield do not fall under the law of armed conflict at all, but under the criminal law." 57 Harold Koh, former Legal Adviser of the Department of State, in a 2010 speech, defended and justified the United States' use of drone strikes and related operations as meeting the requirements of IHL. Koh stated "whether a particular individual will be targeted in a particular location will depend upon considerations specific to each case."58 The principle of proportionality was used as an example because it "prohibits attacks that may be expected to cause incidental loss of civilian life, injury to civilians, damage to civilian objects, or a combination thereof, that would be excessive in relation to the concrete and

\footnotetext{
${ }^{54} \mathrm{R}$ J Vogel "Drone Warfare and the Law of Armed Conflict” [2010] 39 Denv J INT'L \& POL 'Y 101 at 106.

55 Ibid.

${ }^{56}$ Above, $\mathrm{n} 54$ at 108.

${ }^{57}$ Above, n 54 at 109.

${ }^{58} \mathrm{H}$ H Koh "The Obama Administration and International Law" Annual Meeting of the American Society of International Law, Washington DC, 25 March 2010.
} 
direct military advantage anticipated."59 Koh's choice of examples clearly shows that military necessity remains at the forefront of any determination to launch a drone strike. Whether an individual will be targeted, regardless of location "will depend upon considerations specific to each case, including those related to the imminence of the threat, the sovereignty of the other states involved, and the willingness and ability of those states to suppress the threat the target poses." 60 Perhaps somewhat dangerously in terms of IHL, the United States "may conduct ... strikes as long as the individuals ... are lawfully targetable as belligerents or civilians who have forfeited their protected status [as defined under the Hague Convention IV]."61

It must be remembered that in any operation, Article 52 of AP I requires that a target must offer "a definite military advantage."62 Furthermore, the United States Army field manual on the law of war that military necessity is defined as the "principle which justifies those measures not forbidden by international law which are indispensable for securing the complete submission of the enemy as soon as possible." 63 Whether drone strikes meet the military necessity requirements has been described as a relatively easy question to answer. Drones prove invaluable to military operations because of "their ability to find and identify targeted persons and reach into territory that ground forces cannot enter, either for military or political reasons." 64 This is because often, enemy forces will only present themselves for short periods of time, and the ability to take action is often limited. It seems that under current analysis, the territorial requirements of military necessity when conducting operations is a fluid consideration that gives way to the greater objective of whether an operation will offer a definite military advantage for the accomplishment of a military goal, regardless of that goals location.

\footnotetext{
59 Ibid.

60 Ibid.

61 Above, n 54 at $109-110$.

${ }^{62}$ Art 52(2) Protocol Additional to the Geneva Conventions of 12 August 1949, and Relating to the Protection of Victims of International Armed Conflicts (Protocol I), of June 1977.

63 United States Department of Army, Field Manual 27-10: The Law of Land Warfare 14 (2005) at 164.

${ }^{64}$ Above, n 54 at 115.
} 
Distinguishing between a civilian and military objective presents itself as a significant issue for drone strikes, and the ability for the operators of drones to comply with IHL. For example, a person's house may be civilian in status "but when the home is used to house belligerents .... plan or conduct attacks ... or any number of other activities that make an effective contribution the war effort, that home ... changes in such a way that it forfeits its protected civilian status and becomes a military objective." 65 At all times though, regardless of the target and its location, military necessity considerations remain at the forefront of any decision.

\section{MILITARY NECESSITY AND INTERNATIONAL CRIMINAL LAW}

Military necessity acts as an important balancing principle when determining whether a military operation should be conducted. However, after an operation is completed, and the armed conflict is at an end, the opportunity arises for greater scrutiny and investigation of the actions that took place during the armed conflict. Breaches of IHL during armed conflicts often result in war crimes charges. International criminal law imposes liability upon individuals who have allegedly breached fundamental principles of IHL.

Under the Statute of the International Criminal Court (ICC), War crimes are defined under Article 8 and include "[w]ilfull killing and [e]xtensive destruction and appropriation of property, not justified by military necessity and carried out unlawfully and wantonly[.]"66 However, prior to the entry into force of the ICC statute, various criminal tribunals were required to interpret and determine the legality of individual actions in times of war. Military necessity, as a defence, was codified under Article 6 of the Nuremburg Statute. Article 6(b) provided that war crimes included "plunder of public and private property, wanton destruction of cities, towns or villages, or devastation not justified by military necessity." 67 This pronouncement, in the context of post World War Two, is

\footnotetext{
65 Above, n 54 at 122.

${ }^{66}$ Rome Statute of the International Criminal Court (entered into force 1 July 2002), art 2(a)(i) and (iv).

${ }^{67}$ Charter of the International Military Tribunal - Annex to the Agreement for the prosecution and punishment of the major war criminal of the European Axis ("London Agreement), 8 August 1945, art 6(b).
} 
equally applicable to situations of armed conflict today. Military necessity, to be successful as defence, is strictly applied and will only succeed, where it can be shown that military necessity, as understood by IHL, demanded a certain action or response to a situation.

\section{The Nuremberg Trials}

The Nuremberg Trials provided an opportunity for the Military Tribunal presiding to determine pleas of military necessity for alleged war crimes committed during World War II.

In order to determine to what extent military necessity has been used as a defence under IHL at these tribunals, it is important to analyse examples of where this defence has been pleaded. Guidance on military necessity's usage at ICL can be found under Article 6(b) of the Nuremburg Statute. ${ }^{68}$ The Statute provided that war crimes include "plunder of public and private property, wanton destruction of cities, towns or villages, or devastation not justified by military necessity." 69 In contrast, the military tribunals did not accept necessity as a defence in cases involving the summary execution of prisoners of war $^{70}$, the murder or deportation of civilians ${ }^{71}$, the compulsory recruitment of labour from occupied territory ${ }^{72}$, or the seizure of property or goods beyond that which is necessary for the use of the army of occupation ${ }^{73}$. These cases highlight the clear, but strict, parameters of the application of military necessity under ICL, and the extent to which tribunals will accept it as a defence.

The United States Military Tribunal at Nuremberg accepted military necessity as a defence at the trial of the German General Lothar Rendulić. During the German

\footnotetext{
${ }^{68}$ Charter of the International Military Tribunal - Annex to the Agreement for the prosecution and punishment of the major war criminal of the European Axis ("London Agreement), 8 August 1945.

69 Ibid, Art 6(b).

70 Trial of Gunther Thiele and Georg Steinert, Law Reports of Trials of War Criminals, London HMSO 1947-1949, Vol. III (1948) at 59.

71 Trial of Heinz Eck and Four Others (The Pelus Trial), Law Reports of Trials of War Criminals, London HMSO 1947-1949, Vol. XIV (1949) at 106.

72 Trial of Wilhelm von Leeb and Thirteen Others (The German High Command Trial), Law Reports of Trials of War Criminals, London HMSO 1947-1949, Vol. XII (1949) at 93.

73 Trial of Alfried Krupp and Eleven Others (The Krupp Trial), Law Reports of Trials of War Criminals, London HMSO 1947-1949, Vol X (1949) at 138-139.
} 
Army's retreat through Norway, Rendulić engaged in 'scorched earth' tactics in an attempt to slow down the advance of the Russian army that was believed to be behind Rendulić. After raising this as justification for his actions, the Tribunal accepted that " $[\mathrm{t}]$ he destructions of public and private property by retreating military forces which would give aid and comfort to the enemy, may constitute a situation coming within the exceptions contained in Article 23(g) [of the Hague Regulations of 1907]". ${ }^{74}$ Furthermore, the Tribunal held, that as a result of the nature of warfare holding a number of uncertainties including "the numerical strength of the enemy, the quality of his equipment ... and the uncertainty of [an enemies] intentions."75 The Tribunal followed by stating that as a result of the Rendulićs decision to carry out the 'scorched earth' policy was done following an assessment of the conditions as they appeared to Rendulić at the time. Furthermore, relying upon this Rendulić "could honestly conclude that urgent military necessity warranted the decision made, holding that his decisions were justified based on information in his hands at that time."76

After hearing evidence, the Tribunal ultimately rule that the evidence showed that military necessity did not actually exist. However, "Rendulić's genuinely perceived danger of an enemy attack ... should not be second-guessed simply because the full facts as they had become subsequently available contradicted ... his original perception about the danger."77 When considering a war crime, and in cases concerning individual criminal responsibility under ICL, "attention shifts from objective standards [such as the proportionality test] to subjective criteria ('the conditions as they appeared to the defendant at the time')"78

In addition to the Rome Statute of the International Criminal Court, the Statute of the International Criminal Tribunal of the former Yugoslavia represents one of the main reference points for determining individual criminal responsibility for violations of IHL today. Hayashi asserts that where a defendant pleads

\footnotetext{
${ }^{74}$ Above, $\mathrm{n} 38$ at 66.

${ }^{75}$ Above, $\mathrm{n} 73$ at 66-67.

76 Ibid.

${ }^{77}$ Hostage, 11 Trials of War Criminals Before the Nuremberg Military Tribunals Under Control Council Law No. 10 at 1297, in above, n 17 at 95.

${ }^{78}$ Above, n 38 at 66.
} 
military necessity, "the challenges the notion that the crime was committed at all."79

The subjective criteria referred to by the ICTY is an important element to consider, and emphasises the onus upon military commanders during the decision-making process. Furthermore, "[w]here the absence of military necessity is an element of a war crime, the onus rests with the prosecution to show this absence." 80 When asked to determine to what extent damage to property constituted a war crime, the ICTY's Trial Chamber held that to "constitute a grave breach, the destruction unjustified by military necessity must be extensive, unlawful and wanton."

In The Prosecutor v Thiomir Blaškić ${ }^{81}$ (the Blaškić case), following on appeal from the original Trial Chamber, the Appeals Chamber of the ICTY declared that "there is an absolute prohibition on the targeting of civilians in customary international law." 82 This followed an earlier ruling from the Trial Chamber which held that attacks against civilians or civilian objects would only be prohibited if not justified by military necessity. ${ }^{83}$ In another case, concerning the bombardment of the town of Dubrovnik, the ICTY held that "military necessity may be ... defined ... with reference to the widely acknowledge definition of military objectives in Article 52 of [AP I.]"84

\section{J. The ICTY and NATO}

The ICTY was established to prosecute war crimes committed by Yugoslav forces. There were calls for action to be taken against NATO for its action during the campaign. However, the Prosecutor for the ICTY, Carla Del Ponte "stated that she had decided not to open a criminal investigation into any aspect of

\footnotetext{
${ }^{79} \mathrm{~N}$ Hayashi "Requirements of Military Necessity in International Humanitarian Law and International Criminal Law [2010] 28 BUILJ 39 at 132.

80 Ibid.

81 The Prosecutor v Thiomir Blaškić, case No. IT-95 14-T (3 March 2000).

82 The Prosecutor v Thiomir Blaškić, case No. IT-95 14-A (29 July 2014 2014) at para 109.

83 Above, $\mathrm{n} 47$ at para 328.

${ }^{84}$ The Prosecutor $v$ Pavle Strugar case No. IT-01-42-T (31 January 2005) at para 295.
} 
NATO's 1999 air campaign against the [FRY]."85 One of the main reasons to investigate NATO's actions would have been to examine civilian casualties caused by NATO bombing. It is argued that the decision not to prosecute was "tantamount to a judgment of not guilty." 86 This decision was seen as highly controversial, especially when read in light of Article 18 of the ICTY Statute states that the "Prosecutor shall initiate investigations ex officio or on the basis of information obtained from any source[.] ... The Prosecutor shall assess the information received or obtained and decide whether there is sufficient basis to proceed. ${ }^{87}$ In contrast to the number of prosecutions against the Yugoslav forces and government officials, an investigation into NATO actions was deemed unnecessary because its actions arguably adhered to IHL principles.

\section{K. NATO and Breaches of IHL}

However, this finding that NATO acted in accordance with IHL is disputed. Dispute centered around "the methods and policies utilized by NATO forces during the bombing, [and specifically] NATO's ... calculus of military advantage versus civilian casualty[.]"88 Amnesty International (AI) highlighted a number of occasions where it is alleged that NATO violated IHL. On available evidence, AI believed that "whatever their intentions -- NATO forces did commit serious violations of the laws of war leading in a number of cases to the unlawful killings of civilians." 89 While AI, perhaps over optimistically suggests that because a number of member states contributed forces to the NATO operation, "each NATO member may incur responsibility for the military actions carried out under the NATO aegis."90

\footnotetext{
${ }^{85}$ A J Colangelo "Manipulating international criminal procedure: The decision of the ICTY office of the independent prosecutor not to investigate NATO bombing in the former Yugoslavia" [2003] 91 NULR 1393 at 1393.

86 Ibid.

8787 International Tribunal for the Prosecution of Persons Responsible for Serious Violations of International Humanitarian Law Committed in the Territory of the Former Yugoslavia since 1991, adopted 25 May 1993 by Resolution 827, Art 18.

${ }^{88}$ Above, $\mathrm{n} 85$ at 1396.

${ }^{89}$ Amnesty International "NATO/Federal Republic of Yugoslavia “Collateral Damage” or Unlawful Killings? Violations of the Laws of War by NATO during Operation Allied Force" (June 2000) at 1. ${ }^{90}$ Ibid at 11.
} 
Perhaps one of the most noted alleged violations committed by NATO is the attack on the Grdelica railroad bridge. NATO "admitted that its aircraft had bombed the bridge and hit the train, but said that the target had been the bridge itself and that the train had been hit accidentally." ${ }^{91}$ NATO justified the attack, which resulted in civilian casualties, because the mission was to destroy the bridge. The final report into the incident concluded "the passenger train was not deliberately targeted."92 Critics of the Grdelica bridge incident strongly argue that NATO breached IHL, by failing to follow the fundamental rule of distinguishing between military objectives and civilians. However, NATO reasoning after the incident supports the position that, unlike Yugoslav forces, the attack on civilians was unintentional, even if it was could be found that military necessity did not exist.

\section{The ICJ on Military Necessity}

Another advisory opinion from the International Court of Justice (ICJ) provides further clarity into military necessity's interpretation under IHL. The ICJ, when considering the route of the wall built by Israel in the occupied territory examined "certain provisions of the applicable [IHL] enabling account to be taken in certain circumstances of military exigencies[.]"93 For example, article 49(2) of Geneva Convention IV, in reference to an occupying force holds that an occupying force may "undertake total or partial evacuation of a given area if ... imperative military reasons so demand."94 In light of the Israeli Defence Force's construction of the wall, the ICJ found that it could not be justified on the basis of the "absolute necessity of military operations." 95 The ICJ continued to state that the construction of a wall along the route chosen was not "the only means to safeguard the interests of Israel against the peril which it has invoked as justification for that construction." Here, the ICJ's advisory opinion leaves room for other grounds of justification, including state necessity, but for the purposes

\footnotetext{
${ }^{91}$ Above, n 89 at 29.

92 UN ICTY, Prosecutor's Report on the NATO Bombing Campaign, PR/P I.S./510-e (June 13 2000) at para [62].

${ }^{93}$ International Court of Justice "Legal Consequences of the Construction of a Wall in the Occupied Palestinian Territory" Advisory Opinion of 9 July 2004, ICJ Rep (2003) at 55.

${ }^{94}$ Geneva Convention (IV) relative to the Protection of Ciilian Persons in Time of War, (entered into force 12 August 1949).

${ }^{95}$ Above, n 93 at 192.
} 
of military necessity, it shows that where other options may be available to a state to justify a course of action, those should be pursued before turning to military necessity.

\section{Military Necessity under Non International Armed Conflict}

Military necessity is often associated, and has most commonly been used in relation to International Armed Conflicts. However, it also operates as a principle of the law of conflict in Non-International Armed Conflicts (NIAC). In contrast to International Armed Conflict, under the law of NIAC "military necessity is hidden behind different language."96 During a NIAC confrontation, the same permissive and restrictive conditions of military necessity apply. AP II of the Geneva Convention deals specifically with the rules relating to the protection of victims of NIAC. The most emphatic statements on military necessary in AP II comes under Article 17, which prohibits the forced movement of civilians "unless the security of the civilians involved or imperative military reasons so demand."97 The language of article 17 is similar to that contained in other international legal instruments, including AP I.

Difficulty arises, however, out of the very nature of NIAC. Conflicts are not usually symmetrical. Combatants are not two states, but usually the state, versus an insurgent group, of vastly lesser resources and military capability to the government it is fighting. As a result, it becomes vital that principles such as proportionality and distinction are properly adhered to. However, unlike the rules of IHL which are binding upon states, under NIAC there are no binding rules that "define the concept of military objective nor the notion of military advantage, which stem from military necessity[.]"98 As a result of the different nature of the conflict under NIAC, it is suggested that "great caution should be exercised when applying the principle of military necessity." 99 This is because of the great disparity between the parties to the conflict, and it would be

\footnotetext{
${ }^{96}$ Above, $\mathrm{n} 38$ at 72.

${ }^{97}$ Above, n 13, Art 17.

${ }^{98}$ Above, n 38 at 73.

99 Ibid.
} 
inappropriate to apply the same standard, either at IHL or ICL to parties with vastly different training, organisational structures, and resources.

\section{CONCLUSION}

Military necessity is one of the cornerstone principles of IHL. It has played a central role in the conduct of warfare throughout the development of modern armed conflict, beginning with the American Civil War, and continuing throughout conflicts until today. The place and importance of military necessity has been interpreted by a number of authors and international tribunals as a principle that is both permissive and restrictive in what military commanders may or may not do during an armed conflict. Case law has shown what conditions need to exist for a defence of military necessity to be successfully pleaded, specifically the Nuremberg Tribunals and the ICTY have examined individual actions during armed conflict in relation to specific war crimes and offences under ICL. Military necessity is equally an important consideration under international treaty law, working to protect civilians, non-combatants, buildings and property. IHL and ICL operate together to ensure armed conflicts are conducted according to the law, and provide recourse against those who fail to comply with that law.

During the Kosovo Crisis, military necessity was used to justify a range of actions taken by NATO to intervene in Yugoslavia in order to prevent a greater humanitarian crisis. Although controversial, and with much criticism, because no individual from the NATO alliance has been prosecuted before the ICTY, it is implied that NATO's actions were seen as justifiable and necessary under IHL.

Military necessity's future importance ooks certain and its continued use will play an important role in armed conflicts throughout the world in the $21^{\text {st }}$ century. As already demonstrated by the United States use of drone warfare, ensuring appropriate military considerations is vital in any operation. 
VII. BIBLIOGRPAHY

\section{Cases}

The Prosecutor v Thiomir Blaškić, case No. IT-95 14-T (3 March 2000).

The Prosecutor v Thiomir Blaškić, case No. IT-95 14-A (29 July 2014 2014).

The Prosecutor v Pavle Strugar case No. IT-01-42-T (31 January 2005).

Trial of Alfried Krupp and Eleven Others (The Krupp Trial), Law Reports of Trials of War Criminals, London HMSO 1947-1949, Vol X (1949).

Trial of Gunther Thiele and Georg Steinert, Law Reports of Trials of War Criminals, London HMSO 1947-1949, Vol. III (1948).

Trial of Heinz Eck and Four Others (The Pelus Trial), Law Reports of Trials of War Criminals, London HMSO 1947-1949, Vol. XIV (1949).

Hostage, 11 Trials of War Criminals Before the Nuremberg Military Tribunals Under Control Council Law No. 10 at 1297, above, n 17.

Trial of Wilhelm von Leeb and Thirteen Others (The German High Command Trial), Law Reports of Trials of War Criminals, London HMSO 1947-1949, Vol. XII (1949).

\section{Treaties}

Hague Convention (IV) respecting the Laws and Customs of War on Land, 18 October 1907

Charter of the International Military Tribunal - Annex to the Agreement for the prosecution and punishment of the major war criminal of the European Axis ("London Agreement), 8 August 1945.

Protocol Additional to the Geneva Conventions of 12 August 1949, and relating to the Protection of Victims of International Armed Conflicts (Protocol I), of June 1977.

Protocol Additional to the Geneva Conventions of 12 August 1949, and relating to the Protection of Victims of Non-International Armed Conflicts (Protocol II), of 8 June 1977.

International Tribunal for the Prosecution of Persons Responsible for Serious Violations of International Humanitarian Law Committed in the Territory of the Former Yugoslavia since 1991, adopted 25 May 1993 by Resolution 827. 
Rome Statute of the International Criminal Court (entered into force 1 July 2002).

\section{Articles Journal Articles}

Bill B J “The Rendlic 'Rule’: Military Necessity, Commander's Knowledge, and Methods of Warfare” (2009) YIHL 12.

Cohen M "NATO Bombing of Kosovo: Humanitarian Intervention or Crime Against Humanity?" [2002] 79 IJSL.

Colangelo A J "Manipulating international criminal procedure: The decision of the ICTY office of the independent prosecutor not to investigate NATO bombing in the former Yugoslavia" [2003] 91 NULR 1393.

Dunbar, N.C.H. "Military Necessity in War Crimes Trials" [1952] 29 BYIL.

Eikenberry, K “The American Calculus of Military Intervention”, Survival: Global Politics and Strategy, (2014) vol 56 no 3.

Fenrick, W.J. "Targeting and Proportionality during NATO Bombing Campaign against Yugoslavia” [2001] 12 EJIL 489.

Tarcisio Gazzini, Wouter G. Werner and Ige F. Dekker "Necessity Across International Law: An Introduction” (2010) NYIL 41.

Gerald Downey Jr, W "The Law of War and Military Necessity" (1953) 47(2) AJIL 251 at 262 .

Hayashi, N “Requirements of Military Necessity in International Humanitarian Law and International Criminal Law [2010] 28 BUILJ 39.

Luban, D "Military Necessity and the Cultures of Military Law" (2013) Leiden Journal of International Law 26.

McCoubrey, H “Kosovo, Nato and International Law" (1999) 14 International Relations 29.

Schmitt, M N “Military Necessity and Humanity in International Humanitarian Law: Preserving the Delicate Balance" [2010] 50 VJIL 795.

Schwabach, A "The Legality of the NATO Bombing Operation in the Federal Republic of Yugoslavia [1999] 11 Pace Int'l L Rev 405.

Tsagourias, N “Necessity and the Use of Force: A Special Regime” (2010) NYIL 41 at 12 . 
Van Schaack, B \& Madigan, K "Volume 2: International Criminal Law" (2014) International Humanitarian Law Teaching Supplement, Emroy International Humanitarian Law Clinic at 2.

Venturini, G "Necessity in the Law of Armed Conflict and in International Criminal Law" (2010) 41 NYIL 45.

Vogel, R J "Drone Warfare and the Law of Armed Conflict" [2010] 39 Denv J INT'L \& POL 'Y 101.

Wippman D "Kosovo and the Limits of International Law” (2001) 25 Fordham Int'l L.J 129.

\section{Other sources}

Ago, A Addendum - Eighth report on State responsibility by Mr. Roberto Ago, Special Rapporteur - the internationally wrongful act of the State, source of international responsibility YILC (1980)

Amnesty International "NATO/Federal Republic of Yugoslavia "Collateral Damage" or Unlawful Killings? Violations of the Laws of War by NATO during Operation Allied Force" (June 2000).

Amnesty International "NATO violations of the laws of war during Operation Allied Force must be investigated", (25 July 2000)

<www.amnesty.org/news/2000/4/002500.htm>.

Cohen and Shelton "Joint Statement on Kosovo After Action Review in the US Mission to NATO” Security Issues Digest, (14 October 1999).

Human Rights Watch World Report "New Figures on Civilian Deaths in Kosovo War" (7 February 2000) <www.hrw.org/hrw/press/2000/02/nato207/htm>.

International Committee of the Red Cross "Handbook on International Rules Governing Military Operations" ICRC, December 2013.

International Court of Justice, Legality of the Threat or use of Nuclear Weapons, Advisory Opinion of 8 July 1996.

International Court of Justice "Legal Consequences of the Construction of a Wall in the Occupied Palestinian Territory" Advisory Opinion of 9 July 2004, ICJ Rep (2003).

Instructions for the Government of Armies of the United States in the Field (Lieber Code) 24 April 1863.

Koh H H "The Obama Administration and International Law" Annual Meeting of the American Society of International Law, Washington DC, 25 March 2010. 
UN ICTY, Prosecutor's Report on the NATO Bombing Campaign, PR/P I.S./510-e (June 13 2000). 